Article

\title{
Community Leadership in Rural Tourism Development: A Tale of Two Ancient Chinese Villages
}

\author{
Keshuai $\mathrm{Xu}$, Jin Zhang and Fengjun Tian * \\ School of Tourism and Urban Management, Jiangxi University of Finance and Economics, Nanchang 330000, \\ China; xukeshuai306@hotmail.com (K.X.); angelia1027@163.com (J.Z.) \\ * Correspondence:tianfengj98@163.com
}

Received: 21 October 2017; Accepted: 12 December 2017; Published: 15 December 2017

\begin{abstract}
Researchers are paying increasing attention to questions of community leadership and rural tourism development. Based on leadership theories and the literature on community leadership and tourism development, this study developed a framework for community leadership in rural tourism development and used it to examine two ancient Chinese villages. We used the longitudinal case study method to collect data, and we used textual analysis to analyze these data. The results show that the rebel leadership characteristic of confrontational actions played an important role in starting the tourism industry in both villages. However, this leadership was difficult to maintain because community leaders and residents had limited power compared to that of outsiders. Losing control of tourism development in the two villages led to banal management, which prevented the emergence of strong community leadership. In the future, we argue that resilient community leadership should be nurtured in the two villages to address more complex problems occurring in tourism development, such as those characterized by vision tensions and conflicts of interest among the stakeholders affected by tourism development. Finally, we suggest that, based on the longitudinal method, future research can focus on the relationship between resilient leadership and the resilience of tourism communities.
\end{abstract}

Keywords: rural tourism; rebel leadership; resilient leadership; leakage in leadership; banal management; longitudinal studies; rural China

\section{Introduction}

Every human group such as societies, countries, and organizations requires leadership [1]. As a result, leadership has been a key topic discussed by both practitioners and researchers. A great number of studies have paid attention to this topic, providing different perspectives on the essence of leadership [1-17]. According to Northouse, "Leadership is a process whereby an individual influences a group of individuals to achieve a common goal" (p. 6) [15]. This process is a complex interaction between people (leaders and followers) and their social and organizational environments [18]. Thus, to achieve the common goal of a group, leaders and followers have to effectively interact with each other to overcome different types of problems $[19,20]$ caused by the new realities in our dynamic, uncertain, and complex world [5]. These leadership development practices can shape the development stages of social capital in a variety of ways [21]. As a result, individuals can improve their personal lives, and the group can improve its collective effectiveness and performance [15]. Thus, examining and practicing leadership can help us better understand the issue of development, especially in rural areas [22].

From a macro perspective, rural areas are changing rapidly due to different reasons [23-27], becoming places of dynamic, diverse, and contested modes of production, consumption, and protection [25]. 
Responding to these changes, both developing and developed countries have adopted tourism as a useful method to promote community development in rural areas [28-39]. However, tourism is not a panacea for all rural communities $[40,41]$ because different rural communities have different cultures, are in different contexts, and have different resources. As a result, these communities have to face the specific problems of tourism development. Clearly, good community leadership plays a key role in addressing these development issues [22].

Furthermore, in the field of tourism studies and practices, community participation has been used as an effective approach to promote tourism development $[29,42-61]$, because this approach can empower local residents [51], ensuring their control over tourism resources, raising their voice in the decision-making process, and providing them with equitable economic benefits from tourism development [54]. However, participation and empowerment require the direction and structure of strong local leadership [62], because local leaders contribute to community integration and local control over tourism development [50]. Thus, Blackman suggests that leadership is important to increase the community capacity for tourism development [63]. Many studies have focused on the role of local leaders in rural tourism development [30,34,57,64-68]. However, very few studies [34] have adopted the theories developed in leadership studies to explain community leadership in rural tourism development.

In China, tourism has been adopted as a means to improve the rural economy [69]. As a result, tourism has increased considerably in rural communities [32,33,45,70-73]. This situation is especially true in ancient villages $[38,44,70,74,75]$. However, China is a country with a long history of strong centralized governance [76]. This situation is especially true for tourism development in rural China, where the main partnership has been built between local authorities and different types of companies [35]. Numerous cases have proven that local residents lose their control over the decision-making process when powerful local actors, such as local authorities, outside investors, or village despots, engage in tourism development $[42,45,59,75,77,78]$. On the other hand, Yu demonstrates that local leaders in rural China have played an important role in resisting tyranny to protect local residents' rights in a rebellious way [79]. Thus, examining community leadership in rural tourism development contributes to better understanding leadership in a particular political and cultural context [80].

Meanwhile, China is the largest developing country in the world, and this country and its rural areas are experiencing significant changes in different fields [81]. Rural tourism has played a major role in rural transformation and has been impacted by this rapid transformation, undergoing gradual transition [35]. This situation provides both challenges and opportunities for the role played by community leadership in rural tourism development in China, demanding more adaptive leadership to address the more complex and uncertain problems emerging in tourism development.

After reviewing the main theories on leadership and the literature on community leadership and rural tourism development, we have developed a framework for community leadership in rural tourism development. Using this framework, and based on ten years of observation, we analyze community leadership in rural tourism development in two ancient Chinese villages, Langde and Likeng. Next, we describe the interactions among the leaders, followers, and situations at the different phases in the two villages and examine the impact of these interactions on tourism development. We hope that our study, from the perspective of leadership, will provide insights into better practices in rural tourism development and that it will contribute to understanding leadership in rural development in a particular cultural context.

\section{Literature Review and a Theoretical Framework for Community Leadership in Rural Tourism Development}

\subsection{Leadership Theories: A Brief Review}

Leadership is a central issue of human life because, as Locke suggests, "there probably has never been a society, country, or organization that did not have a leader" (p. 1) [1]. Thus, a great number of 
leadership theories have emerged to explain what leadership is and how it develops [1-17]. In general, leadership has three key elements: leaders, followers, and situations. Leadership is a complex process in which people and their social and organizational environments interact with each other [18]. For a group, the purpose of this process is to achieve the common goal of the group by overcoming different types of problems $[19,20]$, especially adaptive challenges [82,83] and complex problems [19]. Personal and collective development can be achieved when the group reaches its common goal.

\subsubsection{Leaders}

First, it is important to differentiate leaders, managers, and pseudo-leaders. All of these people use power to influence followers. However, pseudo-leaders such as Adolf Hitler use coercive power to defend their self-interests rather than to reach the common goal of the group [15]. Regarding the difference between managers and leaders, Kotter argues that managers seek to maintain order and stability while leaders promote change and movement [84]. Additionally, leaders can be emergent or assigned due to the different types of power that they have [15].

Some theories focus more on leaders, examining the traits, skills, behaviors, and ethics of leaders. The trait approach suggests that only some persons with special qualities can be leaders, and thus, a great number of traits that are characteristics of leaders have been identified. Northouse provides a general summary of these traits: intelligence, self-confidence, determination, integrity, and sociability (p. 23) [15]. From the perspective of personality [85], researchers have found a strong correlation between leadership and the Big Five traits (neuroticism, extraversion, openness, agreeableness, and conscientiousness), with extraversion being the most important factor for becoming a leader [86].

The skills perspective suggests that leaders are not born and that leadership can be learned and developed. Kats proposes that a leader can develop three skills: technical skills, human skills, and conceptual skills [87]. In 2000, Munford and colleagues developed a comprehensive skills-based model of leadership that includes five elements: individual attributes competencies, leadership outcomes, career experiences, and environmental influences [88]. The three competencies that compose the key part of this model are problem-solving skills, social judgment skills, and knowledge [88].

Whereas the trait approach and the skills approach focus on the innate qualities of a leader, the behavior approach pays attention to the actions of a leader. Based on two dimensions, concern for production and concern for people, Blake and Mouton develop the Managerial (Leadership) Model to explain the leadership styles that a leader adopts in real situations, including authority-compliance, country club management, impoverished management, team management, and middle-of-the-road management [89]. Based on two factors, supporting behavior and directing behavior, Zigarmi, Zigarmi and Blanchard propose four types of leadership: directing (high directive and low supportive), coaching (high directing and high supportive), supporting (high supportive and low directive), and delegating (low supportive and low directive) [90].

In addition, the Path-Goal Model developed by House and colleagues suggest that there are four styles that a leader can take: directive behavior, which provides guidance and psychological structure; supportive behavior, which provides nurturance; participative behavior, which provides involvement; and achievement-oriented behavior, which provides challenges [91]. Furthermore, the most popular approach to leadership, transformational leadership theory, constructed by Bass and colleagues, suggests three styles of leadership: (1) transactional leadership, which highlights the exchange of labor for rewards; (2) transformational leadership, which provides a group vision, is concerned with the needs of followers, influences followers via the leader's charisma, and motivates followers to achieve the common goal; and (3) laissez-faire leadership, which demonstrates the absence of leadership [92]. Finally, the cultural approach to leadership, adopted by House and colleagues, identifies six global leadership behaviors: charismatic/value-based leadership, team-oriented leadership, participative leadership, humane-oriented leadership, autonomous leadership, and self-protective leadership.

It is important for leaders take ethical responsibility when they lead a group to achieve the common goal because leaders have the power to influence followers [15]. Thus, some leadership 
theories place more emphasis on leadership ethics. The authentic leadership approach suggests that an internalized moral perspective, balanced processing, relational transparency, and moral reasoning are the most important elements of leadership [93]. The servant leadership approach also emphasizes the importance of ethical leadership, highlighting that a leader should put followers first, a leader should help followers grow and succeed, and a leader should behave ethically [94]. Northouse concludes that five principles are key to the development of good ethical leadership: respecting others, serving others, being just, being honest, and building community (pp. 341-346) [15].

\subsubsection{Interaction between Leaders and Followers}

Different leadership theories have different points of view on the relationship between leaders and followers. Followers are ignored in both the trait approach and the skills model [15]. The behavioral approach recognizes the role of followers in the leadership process, highlighting that the leader should use different leadership styles with regard to the development levels of fellowship [95]. However, the role of followers is passive in this approach. Path-goal theory, leader-member exchange (LMX) theory, and the adaptive leadership framework suggest that both leaders and followers play important roles in the leadership process. Path-goal theory identifies four types of followers: dogmatic, unsatisfied, autonomous, and high expectations [96]. A leader should adopt different behaviors to satisfy the needs of followers with different features. LMX emphasizes the dynamics of the relationship between leaders and followers.

According to four factors (roles, influences, exchanges, and interests), this theory describes three phases of leadership making: the stranger phase, the acquaintance phase, and the partnership phase [97]. The adaptive leadership framework highlights that leaders and followers should collaborate with each other to address different types of problems, leading to distributed leadership or multiple leadership [82,83]. Thus, this approach emphasizes the importance of followers' active participation in the leadership process. Finally, servant leadership pays more attention to the needs of followers, suggesting that leaders should serve followers by empowering them and helping them reach their full potential. In addition, the receptivity of followers is key in influencing the performance of servant leadership [94].

\subsubsection{Situations}

According to complexity theory, we are living in a complex system that is characterized by nonlinear and dynamic development [19] and continuing change [5]. Thus, "good leadership requires openness to change on an individual level" (p. 8) [19]. Researchers focusing on leadership have realized the importance of situations in which leadership develops. First, cultural dimensions have a powerful impact on leadership. The most important study on the relationship between culture and leadership was undertaken by House and colleagues. Based on research conducted by Hofstede [98], House and colleagues identified nine cultural dimensions and used these dimensions to develop the regional clusters of world cultures and to then describe the characteristics of each cultural cluster. Each regional culture influences the general leadership style in that region.

Bryman, Stephens, and Campo argue that the micro environment is important when studying leadership [99], because leadership must occur in a given group context [15]. "Change is the only reality" (p. 6) in our complex world, affecting multiple stakeholders in a system and creating value tensions and conflicts of interest between them [5]. Many studies have focused on defining the types of problems that a group will encounter in a real situation. For example, the Cynifin model provides four types of problems: simple problems, complicated problems, complex problems, and chaotic problems. This model suggests that the frequent problems that a group faces in our real world are complex problems, which show that cause and effect can only be deduced in retrospect and that there are no right answers to the question [19]. Meanwhile, the adaptive leadership framework provides three types of challenges: technical challenges, which can be approached through straightforward solutions; technical and adaptive challenges, which can be clearly identified but cannot be addressed 
through existing rules and procedures; and adaptive challenges, which cannot be easily identified and solved [82]. Researchers have provided different perspectives on the role of leadership in addressing these problems. Adaptive leadership theory provides a practical tool for leader behaviors [82,83], and creative leadership theory suggests that leaders should develop diagnostic, visionary, strategic, ideational, evaluative, contextual, and tactical thinking to creatively address complex problems [20].

\subsection{Community Leadership in Rural Tourism Development: A Theoretical Framework}

\subsubsection{Community Leadership and Rural Tourism Development}

Community leadership is a specific form of the general concept of leadership [100]. Goeppinger defines community leadership as the interaction between individuals within a common locale [101]. Based on this definition and the definitions of leadership developed by Northouse [15] and Locke [1], we define community leadership as "a process whereby a community leader influences other community residents to achieve a common goal". Effective community leadership is "key to organizational effectiveness and successful endogenous development activities" [66], contributing to local economic and social development [22]. Tourism has been adopted as an effective way to promote rural community development [28-39]. Thus, many studies have focused on the role of community leadership in tourism development $[30,34,57,63-65,67,68]$. In general, these studies can be categorized into three perspectives: the functions of community leaders, the characteristics of community leaders, and the relationship among community leaders, other residents, and contexts.

(1) The functions of community leaders

Community leaders are those who can influence policy, opinion, or action in a community because of their roles and positions in the community [67]. Thus, these leaders play an important role in community tourism development [30,57,63-65], because they are a key factor in building community collaboration [50,102], developing a partnership with facilitators [29], and maintaining local control over tourism development [75]. On the other hand, most rural people in developing countries still lack the necessary skills and knowledge of tourism and community development $[35,52]$ due to poor basic education and other social services [60]; however, community leaders can protect the rights of the community because of their knowledge and skills [103]. A lack of capable community leaders is often mentioned by local people as being a barrier to community development [68]. Therefore, Murphy argues that it is necessary to directly involve local leadership in tourism development [51].

(2) The characteristics of community leaders

Luloff and colleagues suggest that community leaders are knowledgeable, have problem-solving skills, are capable of influencing other people within the community, and have the ability to influence tourism planning [104]. These capabilities are consistent with the competencies suggested by Munford and colleagues [88]. In addition, local communities require leaders to take the initiative to achieve success in tourism development [65]. Thus, entrepreneurship is a very important character of community leaders who lead other residents to promote rural tourism development $[63,105]$. Pre-existing experiences are also important for community leaders. Aref and Redzuan found that there was a significant positive correlation between age, length of residence, educational level, and length of position held and community capacity building [67], which contributes to tourism development [106]. Finally, Dwyer and Edwards consider that all stakeholders in destinations require "strong, committed and effective leadership" (p. 20) [107]. This suggestion demonstrates that community leaders should be ethical, making a firm commitment to tourism and community development.

(3) The interaction among leaders, other residents, and situations

Richards and Palmer hold that a place should consider political, economic, sociocultural, educational, business, and environmental issues, proposing the concept of "place leadership" to address these complex problems [108]. This opinion can be applied to rural community leadership 
because it is a type of place leadership. Furthermore, Tang and Jones suggest that all stakeholder interests in rural tourism should be represented by developing an accountability framework [34]. Therefore, community leaders "need to engage followers (e.g., small-scale businesses and supporting organizations) to ensure coherent destination development and destination identity" (p. 31) [34]. Based on transformational leadership theory and the Leadership-Exemplary Followership Exchange model [109], Tang and Jones develop a model of leadership for rural tourism development. In this model, Tang and Jones argue that a leader should develop relationships and a culture of followership, motivating followers to move beyond immediate self-interests. Meanwhile, followers should be self-directed and actively engage in tourism development, and the common goal of tourism development within a rural community should be to reach consensus on the destination proposition and to build a coherent rural tourism destination [34].

\subsubsection{Community Leaders in Rural Tourism Development: A Particular Chinese Context}

(1) Traditional culture and the GDP-directed development mode

The main purpose of developing tourism in China, especially in rural China, is to improve the economy $[69,110]$. Directed by a gross domestic product (GDP) orientation, local authorities in China have regarded rural tourism as an important source of government revenue and as a key indicator of high governance performance [75]. This situation is especially true for the county and township governments in remote areas, because, in these areas, other sources of government revenue and other ways by which local officials demonstrate their capabilities are rare. Thus, local authorities in rural China frequently adopt an exogenous development mode by directly engaging in rural tourism development through various means $[32,33,35,45]$. When other powerful actors, such as local authorities and outside investors, engage in tourism development, local residents often cannot maintain control over the tourism industry $[59,75,78]$. As a result, conflicts between villagers and local authorities have emerged $[59,75,78]$.

Culture has a great impact on the leadership process [15]. According to House and colleagues, China is in the cluster of Confucian Asia, and the typical leadership behavior used in China is self-protective [111]. This means that a leader in China frequently utilizes his or her status and position to make decisions, ignoring suggestions by followers [111]. However, some studies demonstrate that other leadership behaviors such as charismatic/value-based leadership and participative leadership can be identified in some rural communities in China [79], including tourism communities [75,112,113].

\section{(2) Rapid Change}

Contemporary Chinese society is full of new realities, and they are a force for change [5] in different fields across the country [81], influencing both rural communities and rural tourism. The major realities include the following: (1) The new political discourse emphasizes the importance of protecting indigenous culture and the ecological environment in rural areas, reducing the gap between rural and urban areas, and improving the role of the local government in rural development [114]; (2) The information technique has been widely used in rural China [115]; (3) Niche markets for rural tourism such as high-end rural inns have emerged [116]. As a result, rural tourism is in transition [35]. Multiple stakeholders will be impacted by this change, creating value tensions as well as meaning and behavior conflicts among stakeholders [5]. These situations require strong community leadership to tackle the different complex problems emerging in rural tourism development.

\subsection{A Theoretical Framework for Community Leadership in Rural Tourism Development}

Based on the above review, we develop a framework for community leadership in rural tourism development (Figure 1) that will be used to explain the dynamics of community leadership in rural tourism development in two ancient Chinese villages. The three elements are community leaders, community residents, and situations. The factors that can influence the effectiveness and performance 
of leaders are personality, competencies, pre-experiences, and ethics. The two characteristics of community residents are active engagement and receptivity. Positive exchanges (collaboration) between community leaders and residents are very important for addressing the different problems occurring in the tourism development process. Thus, distributed or multiple leadership is highlighted in this model. Both the community context and the macro environment construct the complex system in which different stakeholders interact with each other. By overcoming different problems, community leaders and residents can promote tourism development and community development simultaneously. The preservation of tourism resources, economic and employment growth in the tourism industry, and community participation are the three factors for measuring tourism development; meanwhile, quality of life (the material dimension) and the sense of community (the social and emotional dimension) are the two standards for evaluating community development.

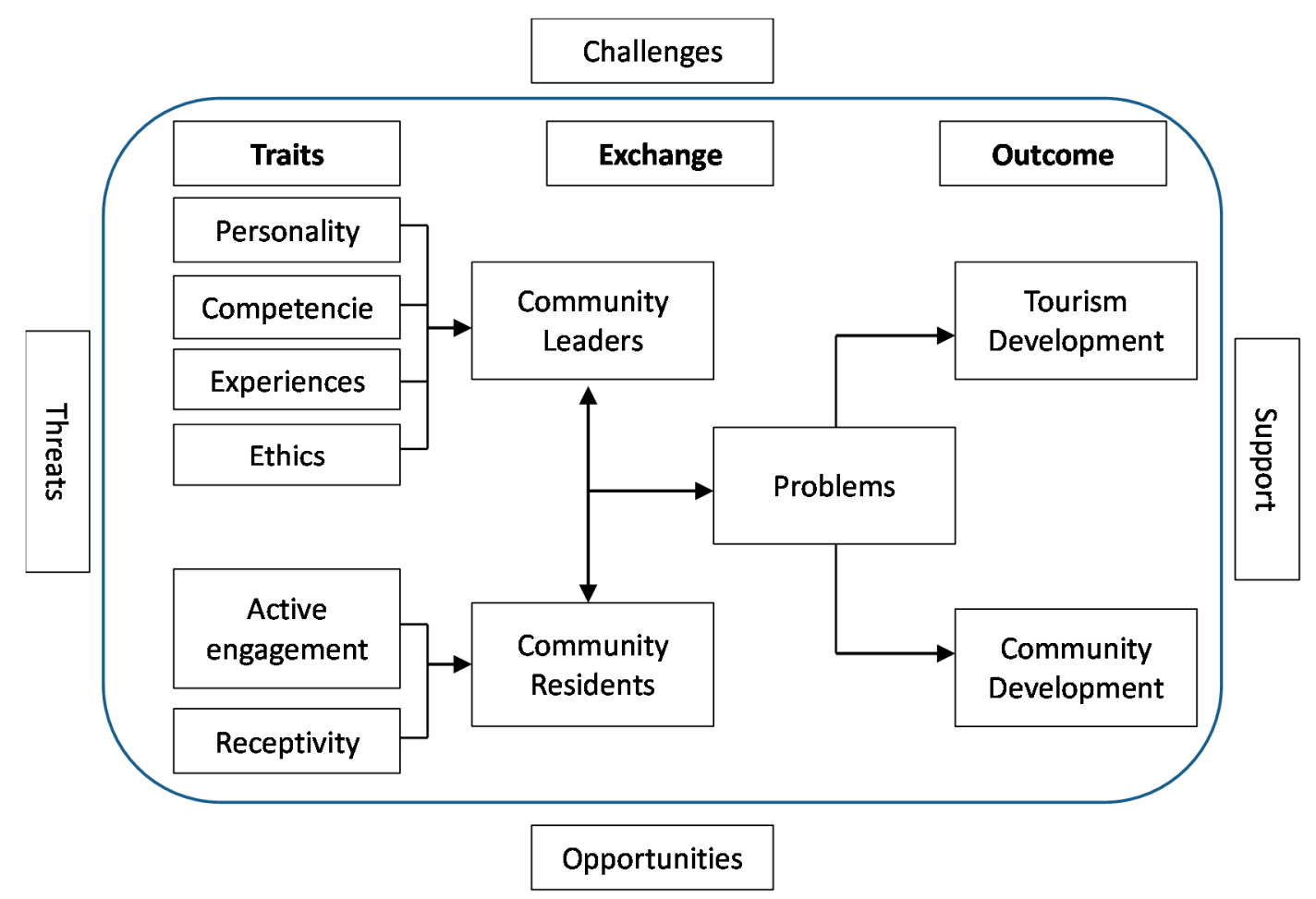

Figure 1. A framework for community leadership in rural tourism development.

\section{Research Methods and Materials}

\subsection{Langd Village and Likeng Village}

Langde Village, located in Leishan County, Guizhou Province, western China (Figure 2), is a minority (Miao) community. The household population of this village was approximately 530 in 2017. Before 2016, this village had been regarded as a successful case of actively involving local residents in tourism development [44] and of preventing the over-commercialization of the Miao heritage of the village [74]. Likeng Village is located in Wuyuan County, Jiangxi Province, central China (Figure 1); in 2017, its household population was approximately 1200. This village is famous for its ancient buildings constructed in the Ming Dynasty [117]. 


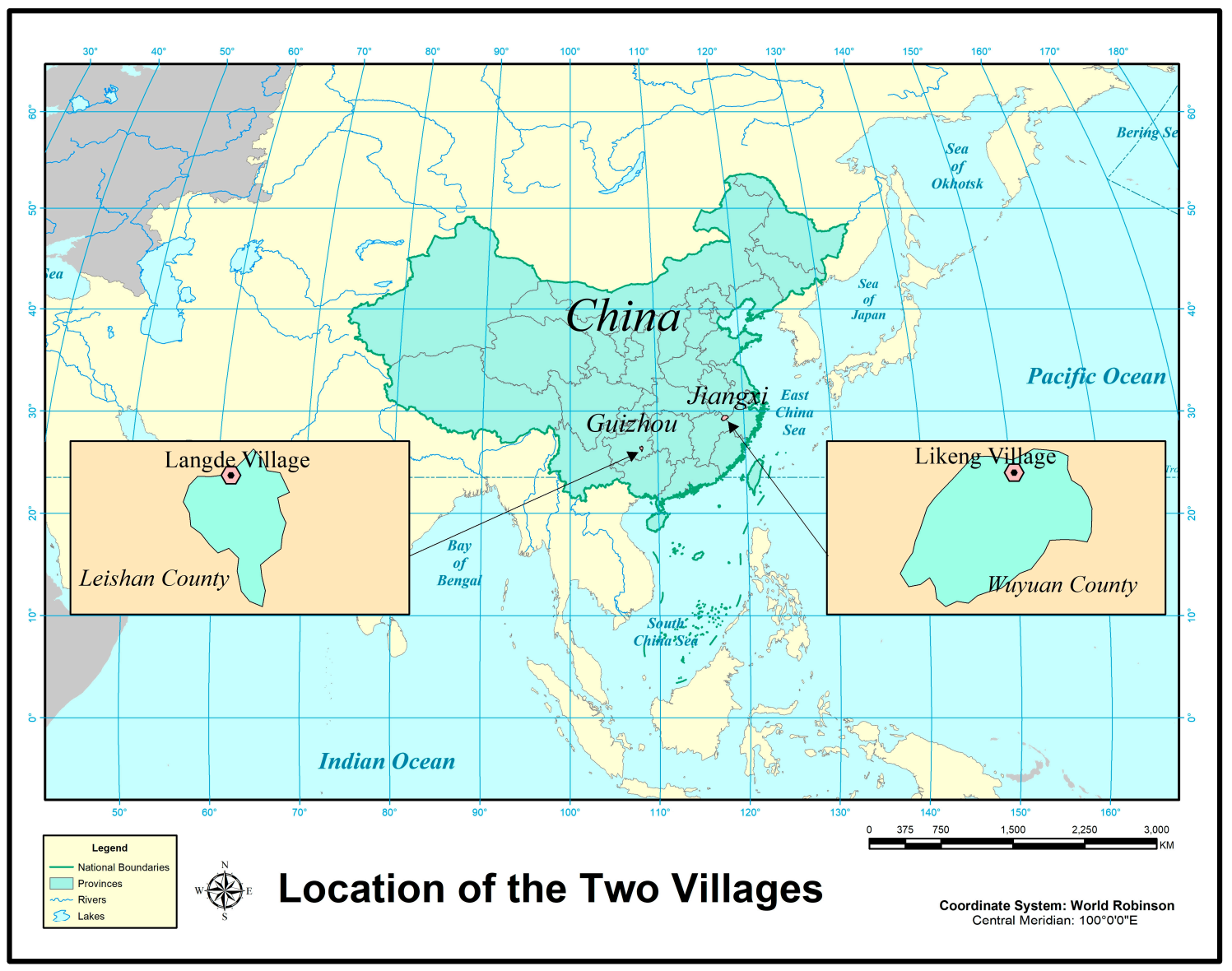

Figure 2. Location of Langde Village and Likeng Village.

\subsection{Methods}

From a longitudinal and comparative perspective, this study adopted a descriptive case-study approach [118]. We observed tourism development in the two villages for ten years in response to the proposals advanced by Pearce [119] and Getz [120]. During the stay in the villages, the first author adopted participatory observation and semi-structured interviews to examine the relationship between community leadership and tourism development. He worked in Langde for two weeks during the summer holiday in 2007 and during the same period in 2008, revisited the village in February 2012 (three days), and interviewed villagers (6 young residents, 3 females, and 3 males) online (via QQ) in September 2017. He also conducted the study in Likeng Village for half a month during the summer holiday in 2007 and revisited it in September 2017 (three days).

During the first author's first stay in the two villages, he collected the data according to the following steps. Initially, he communicated with the business owners in the community because these people are talkative and typically adopt a neutral attitude. Next, he resided in a family inn owned by one of these businesspersons and conducted an in-depth interview with the inn operator. This interview familiarized him with the story of tourism development and allowed him to identify the other informants needed for interviews. He interviewed the informants at night after having been introduced by the inn operator. The innkeeper's introduction helped the subjects feel relaxed enough to present their views. During the day, the first author walked around the village, observing and sometimes holding informal discussions with residents and travelers. These contents were recorded in a notebook after observation and discussion. After interviewing respondents within the community (Table 1), the first author interviewed other stakeholders outside the community such as local officials, facilitators, and tourists (Table 1). 
Table 1. The stakeholders interviewed.

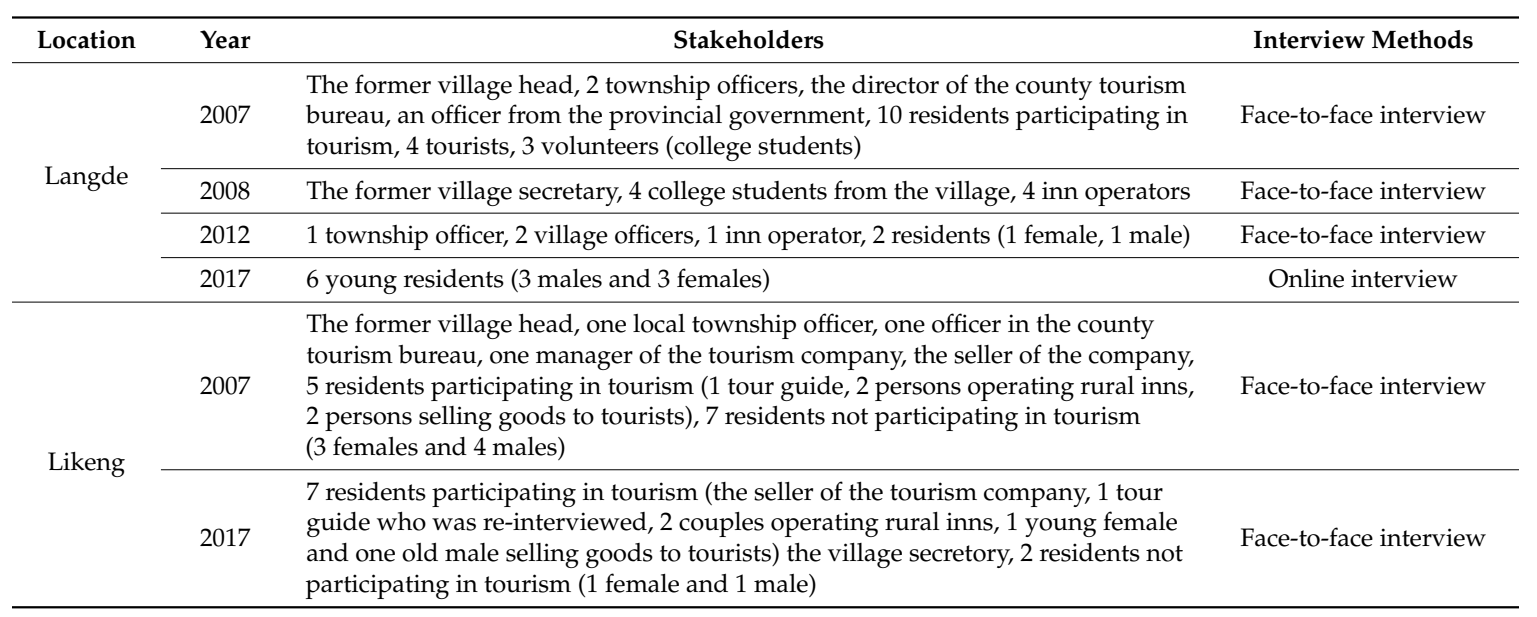

During the subsequent stays, the first author identified the changes related to tourism in both villages and re-interviewed the key stakeholders if possible. Sometimes, new stakeholders were interviewed (Table 1). The first author also used online interviews to gain the latest information about tourism development in Langde. It should be noted that all 6 respondents interviewed via QQ (an instant messaging tool) are young residents, being approximately 20 years old. The respondents directly expressed their opinions about the new method of tourism development in Langde and indirectly outlined the attitudes of other groups.

The main questions that the respondents were asked include the following: (1) What is the process of tourism development in your village? (2) Who plays a key role in tourism development? (3) What are the impacts of tourism development on you, your family, and your community? (4) What is the current problem of tourism development in your community? (5) How should tourism be developed in the future? The individual interviews lasted approximately $30 \mathrm{~min}$ to $1 \mathrm{~h}$, were conducted in Mandarin, and were recorded and transcribed. In Langde Village, we used translators (students in the village) when interviewing old residents who could not understand Mandarin. In addition, other textual or visual resources about the two villages were collected. This evidence supplements the information collected in the two villages and can give us a broader view of the role of community leaders in local control and tourism development.

Finally, based on the framework described above, we used textual analysis to analyze the dynamic relationship between community leadership and rural tourism development in the two villages. Moreno, Noguchi, and Harder suggest that "the iterative triangulation exercise and rigorous cycles of analysis of the findings" (p. 127) can improve the validity of data collected from interviews and field observation [121]. This verification approach was adopted in this study.

\section{Results}

\subsection{Community Leadership and Tourism Development in Langde Village}

\subsubsection{Phase 1 (1985 to 1988): Introducing Tourism into the Community}

\section{(1) Community leaders}

The former village head and the secretary (both veterans) thought that the main purpose of introducing tourism into Langde Village was to improve the economic situation of the village. The village started its tourism project in 1985. At first, some older residents were against tourism development because they thought that it was not appropriate to frequently provide welcoming rituals. The former leaders successfully persuaded these persons. With approval from the residents, some 
trees were cut down and sold (the village has strict regulations to protect forest resources), enabling the village to obtain the capital to develop tourism. This development approach was supported by a scholar from the provincial museum, and the leaders built a good relationship with him.

The former community leaders had to resist intervention by local authorities. After introducing tourism in Langde, local authorities thought that it was the wrong economic approach. To stop this "wrong way", the local authorities set up obstacles at the entrance of the village. Under the leadership of the leaders, the villagers overturned these obstacles. The leaders organized community members to continue to develop the tourism industry.

In 1988, the village began to charge admission fees for traditional performances, and since that time, the revenue of the village has continued to increase. Local authorities wanted to become involved in tourism development to obtain revenue. The county tourism bureau asked the community to accept an outside investor because it believed that outside investment would accelerate tourism development and drive additional revenues. However, the community leaders rejected this proposal, with the support of the villagers. Local officials criticized the community leaders as being short-sighted (for details, see Langde Village enjoying sunshine, the official website of Qiandongnan Prefecture Government, http:/ / www.qdn.gov.cn/page.jsp?urltype=news.NewsContentUrl\&wbnewsid=23317\& wbtreeid=1072), but the villagers did not acquiesce.

Additionally, the scholar helped the community to appeal for funding from the provincial government to restore ancient buildings in the village. For example, the provincial government granted one million yuan to rebuild a corridor bridge, which was typical of the cultural landscape of the village in ancient times, in the village. The funds were withheld by county and township authorities. The community leaders were successful in reclaiming the funds from the local authorities; however, negotiating with the local authorities was very difficult. As one leader said, "If you were not a researcher, I would not talk about this experience again. It was very painful." Through the community members' efforts, Langde has been a successful example of tourism development in the Miao region.

The leaders developed a system to allocate tourism revenue, which was divided into two parts. Thirty percent was owned by the entire community and was used to market tourism and to improve public services. The other 70 percent was distributed monthly among all residents. To allocate this part fairly, the leaders devised a method called "counting work points", which was based on the roles played by local residents in the tourism industry (Table 2). The method shows that the village heads obtain 18 points for each performance; however, the resident who dances and sings in the national costume obtains 24 points. Additionally, information about tourism revenue and distribution was made available to all residents. Thus, this method has been working well since the time of its creation [122].

Table 2. Roles and work points in Langde Upper Village.

\begin{tabular}{cccc}
\hline Roles & Points & Types of National Costume & Points \\
\hline Table leader & 1 & Gown & 10 \\
Greeter & 1 & Ordinary clothes & 9 \\
Lusheng player & 9 & Holiday costumes & 11 \\
Attendant & 6 & Holiday costumes with silver shawl & 15 \\
Singer and dancer & 4 & Holiday costumes with silver shawl and headdress & 20 \\
Students of different ages & $1-5$ & & \\
Manager & 18 & & \\
\hline
\end{tabular}

Source: The Tourism Office of Langde Village. Note: The points in the left row can be added to the points in the right row, with the exception of the points of the manager.

Finally, the former leaders highlighted the importance of protecting local culture. For example, the former secretary said that "tourists visit our village because they love our Miao culture. We must preserve our culture well". Therefore, the leaders formulated strict regulations on protecting the built 
heritage within the community. Meanwhile, they encouraged young people to learn traditional Miao arts and crafts.

(2) Residents' response to leaders and tourism development

Residents in Langde were satisfied with tourism development because everyone in the village could benefit from tourism development, provided that they participated in the operation. The more responsibilities that a resident took on, the higher the level this resident could achieve and, thus, the more income the resident could obtain. In 2007, 48.9 percent of all revenue of the village came from tourism development. The per capita net income of the village was 2756 yuan, 1024 yuan, and 828 yuan more than that of the township level and the county level, respectively (see also the official website of the Qiandongnan Prefecture Government, http:/ / www.qdn.gov.cn/page.jsp? urltype=news. NewsContentUrl\&wbnewsid $=23317 \&$ wbtreeid $=1072$ ).

By actively participating in tourism, the residents of Langde realized that protecting traditional culture is important to the sustainable tourism of the community. Community members preserved their traditional culture through collaborative efforts: for example, the girls were interested in a way to practice traditional crafts [121]. Furthermore, the relationship between residents, along with the relationship between hosts and guests, was harmonious. As one woman stated, "We are a big family."

Finally, the residents in Langde have a very positive image with regard to the former leaders. All the residents interviewed agreed that these leaders played a very important role in promoting tourism development in their village and in improving the quality of life in the village.

\subsubsection{Phase 2 (2008 to 2016): From Prosperity to Decline}

(1) Village heads

The village heads were very busy when tourism development in Langde reached its peak in 2008. In that year, Langde was selected as an important site for relaying the Olympic torch, and this event attracted a large number of tourists. The village typically provided five or six performances per day in the peak season (summer vacation), obtaining three to four thousand yuan each day (not including other income). As a result, the village heads frequently worked 12 to $14 \mathrm{~h}$ per day, organizing the residents to provide performances and traditional Miao cuisine for tourists.

The village heads during this period encountered a great challenge to tourism development in Langde because the number of tourists significantly declined in 2010 due to two reasons: First, the road from Kaili City, the capital of Qiandongnan Prefecture, to Leishan County underwent renovation. This reconstruction discouraged tourists from visiting Langde. Second, the county government brought Xijiang Village, another famous Miao community, into development focus. This adjustment of development priorities led more tourists to Xijiang. When asked how to address this problem, one of the village heads admitted that it was very difficult for him to change the situation.

(2) Residents' response to heads and tourism development

When the number of tourists in Langde significantly declined after 2010, a large number of residents lost their confidence in the village heads and in tourism development. During his three-day stay in 2012, the author observed only one traditional performance. Without sufficient tourists, almost all of the inns (four in 2008) in the village were closed, and a large number of villagers left the community to find work in cities.

\subsubsection{Phase 3 (2016 to Present): Controlled by Outsiders}

\section{(1) Community heads}

In 2016, the village heads completely lost their influence over tourism development because the county government introduced a government-owned company into Langde and started large-scale 
investment in the village (250 million yuan, according to the official report). The company controls tourism resources and the decision-making process of tourism development in the village. A typical example is that for a better economic situation, the former village head joined the company as a department manager.

(2) Residents' response to managers and tourism development

The residents have paradoxical attitudes toward the outside managers. On one hand, these managers have more types of capital than the village heads and residents do. Thus, the community residents hope that the managers can effectively mobilize these capitals to improve tourism and community development. On the other hand, the residents worry that these managers cannot understand the real needs of the residents and do not cherish the cultural heritage in Langde.

The villagers' attitudes toward the new stage of tourism development can be categorized into two types: a large group with fervent hope for the future and a small group with serious concerns about the future. The members of the first group think that under the control of the government-owned tourism company, tourism development in Langde will attract a large number of tourists in the future and that they will be able to gain economic benefits from this growth.

In contrast, the second group worries that the village will be over-commercialized, a situation similar to that of Xijiang, which is controlled by the same company. As a result, the majority of villagers will focus more on maximizing tourism revenue rather than on preserving the ethnic culture, and the harmonious relationship between the villagers and that between hosts and guests will be broken. When asked how to preserve the ethnic culture and maintain the harmonious relationship between hosts and guests, Xiaomei, a student at a famous university in China, described her personal planning: "I am proud of our nation's culture and hope to protect it well. My little brother is learning the lusheng (a Miao musical instrument with multiple bamboo pipes), and in the future, I want to learn Miao embroidery from my mother. Both my mother (Miao embroidery) and my father (lusheng) are the inheritors of an intangible cultural heritage. I will transform our house into a hotel, demonstrating authentic Miao culture to tourists."

\subsection{Community Leadership and Tourism Development in Langde Village}

\subsubsection{Phase 1 (1997 to 2002): Start-Up}

\section{(1) Community leaders}

In Likeng, in 1997, a military veteran was elected by the residents as village head. In the same year, he recommended the development of a tourism industry to improve the quality of life and to preserve the built heritage of the village. The villagers agreed with the recommendation. However, the village lacked the funds to develop tourism without support from the local authorities. The leader asked a successful businessperson who was born in the community for financial support, which he eventually received. Led by the leader, the residents used the funds to restore the ancient buildings and to erect signs for tourists, and they began charging for visits to the village. The tourism revenue was divided into two parts: one for public services and another shared by the residents. As a main contributor to promoting community development and preserving traditional culture, the community leader was recognized as an "Excellent Village Head" by the central government in 2000. (This award was demonstrated by one of the leaders receiving a certificate issued by the Central Party School of the Communist Party of China.)

However, desiring a share of the profits, township officials interfered. The village leader was required to sign a contract with a private company introduced by the township government. Supported by the residents, the leader refused to sign the contract. This rejection irritated local officials, worsening their relationship with the community leader and the majority of residents. In 2002, the leader was deposed at a village meeting controlled by township officials, even though most villagers voted against 
this action. The majority of residents demanded that the local government reorganize the election under the standard procedure. However, this demand was rejected.

More seriously, to completely deprive the community leader of his power in community affairs, local officials helped a pro-government resident become the village head. The residents who supported the leader attempted to petition against the action of the local government. However, these residents were detained and tortured by the local public security agency. The county court imprisoned the leader for two years, trying him for disrupting the social order. The leader was released one year later because the city court determined that he was innocent.

(2) Residents' response to the leader and tourism development

The residents considered that it was better for the community to control tourism development than the outside company. Under community control, tourism development in Likeng augmented the incomes of residents and contributed to preserving the traditional culture. The village was named one of the top 100 folk culture villages in 2000 (reported by People's Daily Overseas Edition. For online information, see http:/ /www.people.com.cn/GB/paper39/1883/302826.html).

The residents in Likeng had an ambivalent attitude toward the former leader. The majority of residents agreed that the leader played a key role in introducing and promoting tourism development in the village. However, some residents thought that the leader was too rigid to handle his relationship with local authorities.

\subsubsection{Phase 2 (2002 to 2016): Controlled by Outside Capital}

(1) Community heads

After introducing a private company to operate the tourism industry of the village in 2002, the role of the new village heads was to receive some tourism revenue paid by the outside companies and to then allocate it to residents. In 2005, according to the residents, this revenue was 30,000 yuan per year. However, this amount was lower than the residents had anticipated. Furthermore, the residents did not know how the money was spent. Over the past 10 years, 6 private companies have successively signed a contract with the community. The reason for this frequent change is that the companies merely collected the entrance fee, ignoring the needed improvements to the facilities and services in the village.

Currently, a private company from Zhejiang Province has the power to collect the admission fee (20 yuan per person). According to the party secretary of Likeng, the village obtains approximately five hundred thousand yuan per year from the new company, with each villager receiving approximately 300 yuan per year. It should be noted that the most conservative estimate of the entrance fees is two million yuan per year.

Additionally, several buildings in the community, which were not listed as protected buildings, were damaged; however, both the village heads and the companies ignored this problem.

(2) Residents' response to the heads and tourism development

After losing control of tourism development, only a few residents continued to be a part of the tourism industry, working for the private company or operating restaurants and inns. In tourism development, the majority of residents were marginalized. As a result, mistrust between the residents and the village heads, the private company, and the local government was high. The residents often expressed their frustration by rejecting or verbally abusing the tourists in their village. In turn, tourists have criticized the village online (for details on tourists' comments on Likeng Village, see Lvping, a net for tourists to share tourism experience, http:/ / www.lvping.com/attraction_review-d446-s17426attraction.html), further damaging the image of the village. 


\subsubsection{Phase 3 (2017): Hybrid Development}

(1) People with power

In addition to the managers of the company and the village heads, businesspeople in Likeng have become an influential group. A number of villagers participate in tourism, operating inns (17), restaurants and bars (14), snack stalls (4), and shops (22). All of these businesses can use electronic payment methods. Among these enterprises, five are larger than others.

Meanwhile, a new economic force has emerged in the village, providing new tourism products for the new niche market. A couple who once operated a business in urban areas returned to the hometown and invested approximately three million yuan to transform their ancient house into a house hotel, opening it in September 2017. The architectural style of the building has been maintained, and different layers of cultural memories have been preserved. The quality of the ancient building repaired by the couple is better than that maintained by the government. (According to one of the respondents, the funds used for renovating this building were one million yuan.) The husband takes responsibility for marketing, building social networks with the outside world; meanwhile, the wife is responsible for welcoming the guests. The average rate per room per night of this inn is 400 yuan, higher than that (100 yuan) of other inns in village. In the first month after its opening, the hotel was operating well.

(2) Residents' response to the heads and tourism development

Whereas the people who directly participate in tourism support tourism development, most of the villagers do not particularly care about the village heads and the tourism development in their village. This situation is represented by a female respondent who stated that "tourism development does not have an impact on us. The company does not contribute to the tourism development in the village. If the village council takes responsibility for managing tourism development in the future, I think that it will also be unable to manage tourism development well. Let nature take its course".

\section{Discussion}

The stories of Langde and Likeng repeat the popular narrative of tourism development in many rural areas in China $[35,45,46,75,77]$. Langde and Likeng have followed a similar path of tourism development: self-control, outside control, and a complex situation requiring change. The result also presents the dynamic development of community leadership in the two villages. Next, we will explain community leadership in rural tourism development based on the framework proposed in the above section.

\subsection{Rebel Leadership: A Key Factor for a Successful Start-Up}

We define the leadership style in the first phase of tourism development in the two villages as rebel leadership. During this phase, the community leaders in both villages were knowledgeable, had pre-experiences and competencies, and rarely considered their personal interests when coping with community affairs. These results are consistent with other research findings $[22,35,53,79]$. Effective and transparent leadership led to equitably distributed tourism revenue, reducing conflicts between residents. Meanwhile, the residents learned to cooperate with one another by actively participating in tourism. When the interests of the community were threatened, local residents needed someone to organize activities to protect their interests. Whether adopting peaceful or violent means, the leaders, as the two cases show, directly confronted powerful actors because they were the representatives of the community. Thus, the receptivity of the residents in two villages was very high during this period. All of these factors contributed to community integration, increasing the power of the community over tourism resources [50]. As a result, in both villages, tourism and community development were significantly improved. 
However, our research shows that the context during the first phase provided little support for improving community leadership in the two villages. Two reasons explain this situation: First, the context at the national level could not provide the necessary support during this phase. China has a long history of strong centralized governance, and this philosophy of governance has not significantly changed in recent years [76,123]. Yang and Wall note that "cultural and political traditions have greatly impeded public participation" (p. 44) [124], and Laverack and Labonte suggest that full community empowerment and participation contribute to strong community leadership [62]. In addition, the main purpose of the Chinese central government in developing rural tourism was to improve the rural economy [69], having less interest in encouraging the self-enhancement of communities [35]. As a result, the space for rural leaders to play roles in tourism development was small. The former leaders in the case of Likeng significantly demonstrate this situation.

Second, the context at the local level also could not provide the necessary support during this phase. Local authorities in rural areas must obtain revenue from tourism development [35]. Thus, they typically engage in the tourism industry by establishing a tourism company or by introducing outside investors to operate the industry $[35,45,75]$. Even supported by community members, the power of leaders is limited compared with that of local authorities or outside investors. Our two case studies also demonstrate these situations for tourism development. Thus, the community leaders and residents had to rebel against the power of outsiders, reducing different types of resources that could be used for better tourism development. In this paper, we define this type of reduction as a leakage in community leadership caused by resistance. We argue that only opening up the discussion between different stakeholders and encouraging dissent and diversity [19] within a community can reduce this type of leakage in community leadership.

\subsection{Banal Management and Poor Development}

We define the behavior of village heads in the second phase as banal management because they sought order and stability rather than adaptive and constructive change [84]; thus, they did "things right" rather than "the right things" (p. 221) [125]. As the two cases show, these managers undertook work based on "the perspectives they acquired through past experience, training, and success" (p. 2) [19]. They did not want to change the current situation or to address emergent issues in a new way. In addition, the relationship between the village heads and community residents became weak, and the communities did not have a clear vision or common goal, as there had been during the first phase. This situation further reduced the capability of the community to address the new development issues.

According to the results, we argue that a lack of strong community leadership leads to external control; external control marginalizes local residents in the decision-making process [46] and results in banal management, preventing the emergence of strong community leadership. This is another type of leakage in community leadership, and we define this leakage as a leakage in community leadership caused by ignorance. The two cases demonstrate the negative impact of this leakage in leadership on tourism development: over-development in Langde and poor investment and preservation in Likeng.

\subsection{New Realities: Nurturing Resilient Leadership in the Future}

Complexity theory suggests that external conditions and systems constantly change. Our studies show that the rural tourism development in both villages has this feature, which is consistent with the results of other studies [34]. Moreover, the current context for tourism development has become more complex than it was before for two reasons: First, more stakeholders (outside capital, local authorities, village heads, different types of businesses, and different types of tourists) engage in tourism development at the community level [33,45]. Vision tensions (the ways of tourism development) and conflicts of interest intensify the complexity of village governance, as demonstrated by this research and other studies [35,46,58,75,126]. Second, at the macro level, technological development [115], the emergence of new tourism niche markets [116], the change in political discourse [114], and the transition of the economic situation [81] construct the broad context for rural tourism. All these 
situations create new realities [5] for community leadership and tourism development, resulting in faster change. This change leads to the emergence of new problems. "Most situations and decisions in organizations are complex because some major change introduces unpredictability and flux" (p. 5), and these complex problems have no right answer and cannot be addressed in terms of existing procedures [19].

A new type of community leadership, which this paper defines as resilient community leadership, is required to respond to the current situation because both rebel leadership and banal management cannot effectively address the complexities of the development problems in the two villages. Complexity theories suggest that the elements in a system interact with each other; these interactions are nonlinear, and minor changes can lead to major consequences. Snowden and Boone provide six tools for addressing complex problems: opening up the discussion, setting barriers, stimulating attractors, encouraging dissent and diversity, managing starting conditions, and monitoring for emergence [19]. According to the above opinions, we find that it is important to stimulate active collaboration between different stakeholders to adopt these tools to address the complex problems that are affecting all stakeholders.

Although all stakeholders should renew their efforts to build a network of cooperation and to share leadership within the network, we mainly focus on community leaders and community residents due to the theme of this paper.

First, it should be noted that in the future, resilient leaders will be emergent rather than assigned in the two villages, and the history of tourism development in both villages will have a major impact on the emergence of resilient leaders. A complex system has a memory $[19,127]$, and "it remains impossible to think in the present without considering the past" (p. 122) [127]. Although we find some potential resilient leaders in both villages who are trying to address new problems in a new way (for example, providing high-end inns), it seems difficult for them to become real resilient leaders in the near future. In both villages, tourism development controlled by outsiders has weakened community leadership, and we argue this situation will continue in the future.

Second, resilient community leaders are the key to developing resilient community leadership in both villages. Potential resilient leaders should learn more to be real resilient leaders in the future. In addition to other attributes such as the experiences, ethics, or skills that a leader should have, the most important thing that a resilient leader should develop is systems thinking and creative thinking because these ways of thinking can improve leaders' problem-solving skills and social judgment skills [88] in a complex system. According to Beerel, a systems thinking mind-set has three elements: big picture thinking, which "seeks out patterns and relationships rather than forces and events" (p. 44), focusing on values and roles, and looking at "the challenges to values and roles as a result of new realities" (p. 47) [5]. In addition, resilient leaders should develop diagnostic, strategic, ideational, evaluative, and tactical thinking to become creative [20]. It should be noted that developing competencies for resilient leaders depends on learning as they interact with their environment and that this development can occur over a long period of time [128]. By developing new ways of thinking, the future leaders in the two villages can identify the basic patterns of adaptive change (competing commitments in Langde and work avoidance in Likeng) [129] in the two villages and establish a new common goal for all stakeholders.

Resilient leadership requires the leader to give the work back to the residents [82]. Currently, the majority of residents in the two villages ignore their roles in tourism development (an indifferent attitude toward tourism development in Likeng and a high dependence on outsiders in Langde), weakening community leadership in the two villages. Thus, future community leaders in both villages should encourage their followers to share leadership and responsibility in tourism development. First, future community leaders should identify the drive that can motivate residents to actively participate in the leadership process. Second, future leaders should create a holding environment in which residents can feel safe to address problems. Finally, considering the capacities of ordinary residents in 
the two villages, future leaders should state fewer problems and simple problems to be addressed at the earlier phase.

\section{Conclusions}

This study developed a framework for explaining community leadership in rural tourism development. Based on this framework, we identified three phases of tourism development in Langde and Likeng and proposed three types of community leadership for different phases, demonstrating that community leadership plays an important role in rural tourism development. However, both macro and micro environments have an impact on community leadership in tourism development. We suggest that banal management, which is caused by outside control of tourism development, and rebel leadership, which is caused by intense opposition between the community and the local government, will lead to a leakage in community leadership. In the future, we suggest that resilient leadership should be nurtured in the two villages to increase community leadership, which will contribute to addressing more complex problems of tourism development. We hope our case studies will provide insights into community leadership in rural tourism development in China, and can contribute to better practices of tourism development in ancient Chinese villages.

Our research has also proven that the longitudinal comparative case method is a useful way to monitor tourism development in rural communities in the long run. We suggest that more longitudinal studies can be undertaken in the future to describe the dynamic development of tourism development in rural communities and to analyze complex problems such as value tension and conflicts of interest among stakeholders. In addition, this study used a qualitative method, which has some limitations in explaining the complex change produced in tourism development. In the future observation of the two villages, we will use mixed methods to describe the changing issues and to examine the factors impacting these issues. Finally, we suggest that future studies can focus on the relationship between resilient leadership and the resilience of tourism communities. In addition, the local government is an important stakeholder in rural tourism development in China, and its impact in community leadership development warrants further examination.

Acknowledgments: This study was supported by a grant from the Jiangxi Provincial Natural Science Foundation (No. 20161BAB203095).

Author Contributions: All the authors have contributed in the conceptual research design and writing of this manuscript. Keshuai $\mathrm{Xu}$ conducted the primary data collection, analyses and preliminary drafting of the research article. Fengjun Tian supervised the whole research process, including data collection and analyses, and revising the manuscript. Jin Zhang has read the entire manuscript for critical commentary.

Conflicts of Interest: The authors declare no conflict of interest.

\section{References}

1. Locke, E.A. The Essence of Leadership: The Four Keys to Leading Successfully; Lexington Books: Lanham, MD, USA, 1999.

2. Antonakis, J.; Day, D.V. The Nature of Leadership; Sage Publications: Thousand Oaks, CA, USA, 2017.

3. April, K.A.; Macdonald, R.; Vriesendorp, S. Rethinking Leadership; Juta and Company Ltd.: Cape Town, South Africa, 2000.

4. Bass, B.M.; Stogdill, R.M. Bass E Stogdill's Handbook of Leadership: Theory, Research, and Managerial Applications; Simon and Schuster: New York, NY, USA, 1990.

5. Beerel, A. Leadership and Change Management; Sage: Thousand Oaks, CA, USA, 2009.

6. Bryman, A. Charisma and Leadership in Organizations; Sage Publications: Thousand Oaks, CA, USA, 1992.

7. Bryman, A. The SAGE Handbook of Leadership; Sage Publications: Thousand Oaks, CA, USA, 2011.

8. Carroll, B.; Ford, J.; Taylor, S. Leadership: Contemporary Critical Perspectives; Sage Publications: Thousand Oaks, CA, USA, 2015.

9. Day, D.V. The Oxford Handbook of Leadership and Organizations; Oxford University Press: Oxford, UK, 2014. 
10. DuBrin, A.J. Leadership: Research Findings, Practice, and Skills; Nelson Education: Scarborough, ON, Canada, 2015.

11. Gardner, J. On Leadership; Simon and Schuster: New York, NY, USA, 1993.

12. Hickman, G.R. Leading Organizations: Perspectives for a New Era; Sage Pulications: Thousand Oaks, CA, USA, 1998.

13. Mumford, M.D. Pathways to Outstanding Leadership: A Comparative Analysis of Charismatic, Ideological, and Pragmatic Leaders; Lawrence Erlbaum Associates Publishers: Mahwah, NJ, USA, 2006.

14. Khan, Z.A.; Nawaz, A.; Irfanullah, K. Leadership theories and styles: A literature review. J. Resour. Dev. Manag. 2016, 16, 1-16.

15. Northouse, P.G. Leadership: Theory and Practice; Sage Publications: Thousand Oaks, CA, USA, 2015.

16. Rost, J.C. Leadership for the Twenty-First Century; Greenwood Publishing Group: Santa Barbara, CA, USA, 1993.

17. Stogdill, R.M. Handbook of Leadership: A Survey of Theory and Research; Free Press: New York, NY, USA, 1974.

18. Day, D.V. Leadership development: A review in context. Leadersh. Q. 2001, 11, 581-613. [CrossRef]

19. Snowden, D.J.; Boone, M.E. A leader's framework for decision making. Harv. Bus. Rev. 2007, 85, 68-76. [PubMed]

20. Puccio, G.J.; Mance, M.; Murdock, M.C. Creative Leadership: Skills that Drive Change; Sage Publications: Thousand Oaks, CA, USA, 2010.

21. Galli, E.B.; Müller-Stewens, G. How to build social capital with leadership development: Lessons from an explorative case study of a multibusiness firm. Leadersh. Q. 2012, 23, 176-201. [CrossRef]

22. Sorensen, T.; Epps, R. Leadership and local development: Dimensions of leadership in four central Queensland towns. J. Rural Stud. 1996, 12, 113-125. [CrossRef]

23. Woods, M. Engaging the global countryside: Globalization, hybridity and the reconstitution of rural place. Prog. Hum. Geogr. 2007, 31, 485-507. [CrossRef]

24. Holmes, J. Impulses towards a multifunctional transition in rural Australia: Gaps in the research agenda. J. Rural Stud. 2006, 22, 142-160. [CrossRef]

25. Holmes, J. Impulses towards a multifunctional transition in rural Australia: Interpreting regional dynamics in landscapes, lifestyles and livelihoods. Landsc. Res. 2008, 33, 211-223. [CrossRef]

26. Holmes, J. Cape York Peninsula, Australia: A frontier region undergoing a multifunctional transition with indigenous engagement. J. Rural Stud. 2012, 28, 252-265. [CrossRef]

27. Ilbery, B. The Geography of Rural Change; Routledge: London, UK, 2014.

28. Dashper, K. Rural tourism: Opportunities and challenges. In Rural Tourism: An International Perspective; Dashper, K., Ed.; Cambridge Scholars Publishing: Newcastle upon Tyne, UK, 2015; pp. 1-21.

29. Verbole, A. Actors, discourses and interfaces of rural tourism development at the local community level in Slovenia: Social and political dimensions of the rural tourism development process. J. Sustain. Tour. 2000, 8 , 479-490. [CrossRef]

30. Wilson, S.; Fesenmaier, D.R.; Fesenmaier, J.; Van Es, J.C. Factors for success in rural tourism development. J. Travel Res. 2001, 40, 132-138. [CrossRef]

31. Bureau, N.T. Typical Cases of Rural Tourism Development; China Travel Publishing House: Beijing, China, 2007.

32. Gao, S.; Huang, S.; Huang, Y. Rural tourism development in China. Int. J. Tour. Res. 2009, 11, 439-450. [CrossRef]

33. Su, B. Rural tourism in China. Tour. Manag. 2011, 32, 1438-1441. [CrossRef]

34. Haven-Tang, C.; Jones, E. Local leadership for rural tourism development: A case study of Adventa, Monmouthshire, UK. Tour. Manag. Perspect. 2012, 4, 28-35. [CrossRef]

35. Li, P.; Ryan, C.; Cave, J. Chinese rural tourism development: Transition in the case of Qiyunshan, Anhui-2008-2015. Tour. Manag. 2016, 55, 240-260. [CrossRef]

36. Chen, X. A phenomenological explication of guanxi in rural tourism management: A case study of a village in China. Tour. Manag. 2017, 63, 383-394. [CrossRef]

37. Fong, S.-F.; Lo, M.-C.; Songan, P.; Nair, V. Self-efficacy and sustainable rural tourism development: Local communities' perspectives from Kuching, Sarawak. Asia Pac. J. Tour. Res. 2017, 22, 147-159. [CrossRef]

38. Gao, J.; Wu, B. Revitalizing traditional villages through rural tourism: A case study of Yuanjia Village, Shaanxi Province, China. Tour. Manag. 2017, 63, 223-233. [CrossRef]

39. Hwang, D.; Stewart, W.P. Social capital and collective action in rural tourism. J. Travel Res. 2017, 56, 81-93. [CrossRef] 
40. Ryan, C.; Page, S. Tourism Management; Routledge: London, UK, 2012.

41. Phillips, R.; Roberts, S. Tourism, Planning, and Community Development; Routledge: London, UK, 2013.

42. Bao, J.; Sun, J. Differences in community participation in tourism development between China and the West. Chin. Sociol. Anthropol. 2007, 39, 9-27.

43. Blackstock, K. A critical look at community based tourism. Community Dev. J. 2005, 40, 39-49. [CrossRef]

44. Chen, Z.; Li, L.; Li, T. The Organizational Evolution, Systematic Construction and Empowerment Significance of Langde Miao's Community Tourism. Tour. Trib. 2013, 28, 75-86. (In Chinese)

45. Huang, S.S.; Chen, G. Tourism Research in China: Themes and Issues; Channel View Publications: Bristol, UK, 2015.

46. Li, W. Community decisionmaking participation in development. Ann. Tour. Res. 2006, 33, 132-143. [CrossRef]

47. Mak, B.K.; Cheung, L.T.; Hui, D.L. Community participation in the decision-making process for sustainable tourism development in rural areas of Hong Kong, China. Sustainability 2017, 9, 1695. [CrossRef]

48. Manyara, G.; Jones, E. Community-based tourism enterprises development in Kenya: An exploration of their potential as avenues of poverty reduction. J. Sustain. Tour. 2007, 15, 628-644. [CrossRef]

49. Matarrita-Cascante, D.; Brennan, M.A.; Luloff, A. Community agency and sustainable tourism development: The case of La Fortuna, Costa Rica. J. Sustain. Tour. 2010, 18, 735-756. [CrossRef]

50. Mitchell, R.E.; Reid, D.G. Community integration: Island tourism in Peru. Ann. Tour. Res. 2001, $28,113-139$. [CrossRef]

51. Murphy, P.E. Tourism: A Community Approach (RLE Tourism); Routledge: London, UK, 2013.

52. Ndivo, R.M.; Cantoni, L. Rethinking local community involvement in tourism development. Ann. Tour. Res. 2016, 57, 275-278. [CrossRef]

53. Nyaupane, G.P.; Morais, D.B.; Dowler, L. The role of community involvement and number/type of visitors on tourism impacts: A controlled comparison of Annapurna, Nepal and Northwest Yunnan, China. Tour. Manag. 2006, 27, 1373-1385. [CrossRef]

54. Pearce, D.G. Alternative tourism: Concepts, classifications, and questions. In Tourism Alternatives: Potentials and Problems in the Development of Tourism; Smith, V.L., Eadington, W.R., Eds.; University of Pennsylvania Press: Philadelphia, PA, USA, 1992; pp. 15-30.

55. Rasoolimanesh, S.M.; Jaafar, M.; Ahmad, A.G.; Barghi, R. Community participation in World Heritage Site conservation and tourism development. Tour. Manag. 2017, 58, 142-153. [CrossRef]

56. Simpson, K. Strategic planning and community involvement as contributors to sustainable tourism development. Curr. Issues Tour. 2001, 4, 3-41. [CrossRef]

57. Simpson, M.C. An integrated approach to assess the impacts of tourism on community development and sustainable livelihoods. Community Dev. J. 2009, 44, 186-208. [CrossRef]

58. Sun, J.; Bao, J. The community participation model of tourism: An empirical study of Yunnan and Guangxi. China Tour. Res. 2006, 2, 130-145.

59. Sun, J.X.; Bao, J.G. Tourism anthropology analysis on community participation: A case study of Yulong River in Yangshuo. J. Guangxi Univ. Nationalities (Philos. Soc. Sci. Ed.) 2005, 27, 85-92. (In Chinese)

60. Tosun, C. Limits to community participation in the tourism development process in developing countries. Tour. Manag. 2000, 21, 613-633. [CrossRef]

61. Tosun, C. Stages in the emergence of a participatory tourism development approach in the Developing World. Geoforum 2005, 36, 333-352. [CrossRef]

62. Laverack, G.; Labonte, R. A planning framework for community empowerment goals within health promotion. Health Policy Plan. 2000, 15, 255-262. [CrossRef] [PubMed]

63. Blackman, A. Perspectives on leadership coaching for regional tourism managers and entrepreneurs. In Building Community Capacity for Tourism Development; Moscardo, G., Ed.; CABI: Wallingford, UK, 2008; pp. 142-154.

64. Mendoza-Ramos, A.; Prideaux, B. Assessing ecotourism in an Indigenous community: Using, testing and proving the wheel of empowerment framework as a measurement tool. J. Sustain. Tour. 2017, 1-15. [CrossRef]

65. Aref, F.; Redzuan, M.; Emby, Z. Assessing community leadership factor in community capacity building in tourism development: A case study of Shiraz, Iran. J. Hum. Ecol. 2009, 28, 171-176. [CrossRef]

66. Davies, A. Local leadership and rural renewal through festival fun: The case of SnowFest. In Festival Places: Revitalising Rural Australia; Channel View Publications: Bristol, UK, 2011; pp. 61-73. 
67. Aref, F.; Redzuan, M. Community Leaders' Characteristic and their Effort in Building Capacity for Tourism Development in Local Communities. Int. J. Bus. Manag. 2009, 4, 187. [CrossRef]

68. Aref, F.; Ma'rof, B. Barriers to Community Leadership towards Tourism Development in Shiraz, Iran. Eur. J. Soc. Sci. 2008, 7, 172-178.

69. Ryan, C.; Huang, S. The role of tourism in China's transition: An introduction. In Tourism in China: Destinations, Planing and Experiences; Ryan, C., Huang, S., Eds.; Channel View Publications: Bristol, UK, 2013; pp. 1-10.

70. Lin, J.; Cai, J.; Han, Y.; Liu, J. Identifying the conditions for rural sustainability through place-based Culture: Applying the CIPM and CDPM models into Meibei ancient village. Sustainability 2017, 9, 1334. [CrossRef]

71. Xue, L.; Kerstetter, D.; Hunt, C. Tourism development and changing rural identity in China. Ann. Tour. Res. 2017, 66, 170-182. [CrossRef]

72. Zhou, L.; Chan, E.; Song, H. Social capital and entrepreneurial mobility in early-stage tourism development: A case from rural China. Tour. Manag. 2017, 63, 338-350. [CrossRef]

73. Liu, S.; Cheng, I.; Cheung, L. The roles of formal and informal institutions in small tourism business development in rural areas of south China. Sustainability 2017, 9, 1194. [CrossRef]

74. Xu, K.; Yan, T.; Zhu, X. Commodification of Chinese heritage villages. Ann. Tour. Res. 2013, 40, 415-419. [CrossRef]

75. Ying, T.; Zhou, Y. Community, governments and external capitals in China's rural cultural tourism: A comparative study of two adjacent villages. Tour. Manag. 2007, 28, 96-107. [CrossRef]

76. McCormack, J.; Blair, J.G. Thinking through China; Rowman \& Littlefield: Washington, DC, USA, 2015.

77. Weng, S.X.; Peng, H. The impact of power relationship on community participation in tourism development: A case from Furong Village at Nanxi River Basin, Zhejiang Province. Tour. Trib. 2010, 25, 51-57. (In Chinese)

78. Yu, Y.F. Attractions in Wuyuan County Shut Down Due to Conflict of Interests. Available online: http: / /zqb.cyol.com/html/2011-08/17/nw.D110000zgqnb_20110817_4-02.htm (accessed on 9 September 2017).

79. Yu, J.R. Contentious Politics: Fundamental Isuues in Chinese Political Sociology; People's Publishing House: Beijing, China, 2010. (In Chinese)

80. Dorfman, P.W.; Hanges, P.J.; Brodbeck, F.C. Leadership and cultural variation: The identification of culturally endorsed leadership profiles. In Culture, Leadership, and Organizations: The GLOBE Study of 62 Societies; Dorfman, P.W., Hanges, P.J., Brodbeck, F.C., Eds.; Sage Publications: Thousand Oaks, CA, USA, 2004; pp. 669-719.

81. Mok, K.-H.; Wang, L. Handbook of Contemporary China; World Scientific: Singapore, 2011.

82. Heifetz, R.A. Leadership without Easy Answers; Harvard University Press: Cambridge, MA, USA, 1994.

83. Heifetz, R.A.; Laurie, D.L. The work of leadership. Harv. Bus. Rev. 1997, 75, 124-134. [PubMed]

84. Kotter, J.P. Force for Change: How Leadership Differs from Management; Simon and Schuster: New York, NY, USA, 2008.

85. Goldberg, L.R. An alternative "description of personality": The big-five factor structure. J. Personal. Soc. Psychol. 1990, 59, 1216-1229. [CrossRef]

86. Judge, T.A.; Bono, J.E.; Ilies, R.; Gerhardt, M.W. Personality and leadership: A qualitative and quantitative review. J. Appl. Psychol. 2002, 87, 765-780. [CrossRef] [PubMed]

87. Katz, R. Skills of an effective administrator. Harv. Bus. Rev. 1955, 33, 33-42.

88. Mumford, M.D.; Zaccaro, S.J.; Harding, F.D.; Jacobs, T.O.; Fleishman, E.A. Leadership skills for a changing world: Solving complex social problems. Leadersh. Q. 2000, 11, 11-35. [CrossRef]

89. Blake, R.R.; Mouton, J.S. The Managerial Grid; Gulf Publishing Company: Houston, UK, 1964.

90. Zigarmi, P.; Zigarmi, D.; Blanchard, K. Leadership and the One Minute Manager; FontanaCollins: New York, NY, USA, 1987.

91. House, R.J.; Mitchell, T.R. Path-goal theory of leadership. J. Contemp. Bus. 1974, 3, 81-97.

92. Bass, B. Leadership and Performance beyond Expectations; Free Press: New York, NY, USA, 1985.

93. Gardner, W.L.; Avolio, B.J.; Luthans, F.; May, D.R.; Walumbwa, F. “Can you see the real me? " A self-based model of authentic leader and follower development. Leadersh. Q. 2005, 16, 343-372.

94. Liden, R.C.; Wayne, S.J.; Zhao, H.; Henderson, D. Servant leadership: Development of a multidimensional measure and multi-level assessment. Leadersh. Q. 2008, 19, 161-177. [CrossRef]

95. Blake, R.R.; McCanse, A.A. Leadership Dilemmas_Grid Solutions; Gulf Professional Publishing: Houston, TX, USA, 1991.

96. House, R.J. A path goal theory of leader effectiveness. Adm. Sci. Q. 1971, 16, 321-339. [CrossRef] 
97. Graen, G.B.; Uhl-Bien, M. Relationship-based approach to leadership: Development of leader-member exchange (LMX) theory of leadership over 25 years: Applying a multi-level multi-domain perspective. Leadersh. Q. 1995, 6, 219-247. [CrossRef]

98. Hofstede, G. Culture's Consequences: Comparing Values, Behaviors, Institutions and Organizations across Nations; Sage Publications: Thousand Oaks, CA, USA, 2003.

99. Bryman, A.; Stephens, M.; a Campo, C. The importance of context: Qualitative research and the study of leadership. Leadersh. Q. 1996, 7, 353-370. [CrossRef]

100. Andersen, L.; O'Loughlin, P.; Salt, A. Community Leadership Programs in New South Wales, UTS Shopfront; The Strengthening Communities Unit, NSW Premier's Department: Sydney, Australia, 2001.

101. Goeppinger, A. The fallacies of our reality: A deconstructive look at community and leadership. Int. J. Leadersh. Educ. 2002, 5, 77-83. [CrossRef]

102. Raik, D.B.; Decker, D.J.; Siemer, W.F. Dimensions of capacity in community-based suburban deer management: The managers' perspective. Wildl. Soc. Bull. 2003, 31, 854-864.

103. Thompson, B.; Lichtenstein, E.; Corbett, K.; Nettekoven, L.; Feng, Z. Durability of tobacco control efforts in the 22 Community Intervention Trial for Smoking Cessation (COMMIT) communities 2 years after the end of intervention. Health Educ. Res. 2000, 15, 353-366. [CrossRef] [PubMed]

104. Luloff, A.E.; Bridger, J.C.; Graefe, A.R.; Saylor, M.; Martin, K.; Gitelson, R. Assessing rural tourism efforts in the United States. Ann. Tour. Res. 1994, 21, 46-64. [CrossRef]

105. Moscardo, G. Tourism and community leadership in rural regions: Linking mobility, entrepreneurship, tourism development and community well-being. Tour. Plan. Dev. 2014, 11, 354-370. [CrossRef]

106. Moscardo, G. Building Community Capacity for Tourism Development; CABI: Wallingford, TX, USA, 2008.

107. Dwyer, L.; Edwards, D. Sustainable tourism planning. In Understanding the Sustainable Development of Tourism; Liburd, J.J., Edwards, D., Eds.; Goodfellow Publishers Limited: Oxford, UK, 2010; pp. 19-44.

108. Richards, G.; Palmer, R. Eventful Cities: Cultural Management and Urban Revitalisation; Butterworth-Heinemann: Oxford, UK, 2010.

109. Pitron, J. The Influence of Exemplary Followership on Organizational Performance: A Phenomenological Approach. Ph.D. Dissertation, University of Phoenix, Phoenix, AZ, USA, 2008.

110. Dai, B.; Jiang, Y.; Yang, L.; Ma, Y. Stage characteristics and policy choices of China's outbound tourism development. Tour. Trib. 2013, 28, 39-45. (In Chinese)

111. House, R.J.; Hanges, P.J.; Javidan, M.; Dorfman, P.W.; Gupta, V. Culture, Leadership, and Organizations: The GLOBE Study of 62 Societies; Sage Publications: Thousand Oaks, CA, USA, 2004.

112. Gu, H.; Ryan, C. Hongcun, China-Residents' Perceptions of the Impacts of Tourism on a Rural Community: A Mixed Methods Approach. J. China Tour. Res. 2010, 6, 216-243. [CrossRef]

113. Wen, T.J. The Practice of Building New Countryside in China; Wenjin Press: Beijing, China, 2006.

114. Long, H.; Liu, Y.; Li, X.; Chen, Y. Building new countryside in China: A geographical perspective. Land Use Policy 2010, 27, 457-470. [CrossRef]

115. Xia, J. Linking ICTs to rural development: China's rural information policy. Gov. Inf. Q. 2010, 27, 187-195. [CrossRef]

116. Pi, C.; Zheng, X. Customers' Complaints about Bed and Breadfast Based on Online Reviews Analysis: A Case Study of Xiamen. Tour. Forum 2017, 3, 35-44.

117. Guo, M.F. Likeng: Living Environment in an Ancient Village; China Meteorological Press: Beijing, China, 2008. (In Chinese)

118. Yin, R.K. Case Study Research: Design and Methods; Sage Publications: Thousand Oaks, CA, USA, 2013.

119. Pearce, D.G. Comparative studies in tourism research. In Tourism Research: Critiques and Challenges; Pearce, D.G., Butler, R.W., Eds.; Routledge: London, UK, 1993; pp. 20-35.

120. Getz, D. Residents' attitudes towards tourism: A longitudinal study in Spey Valley, Scotland. Tour. Manag. 1994, 15, 247-258. [CrossRef]

121. Moreno, J.M.; Noguchi, L.M.; Harder, M.K. Understanding the Process of Community Capacity-Building: A Case Study of Two Programs in Yunnan Province, China. World Dev. 2017, 97, 122-137. [CrossRef]

122. Li, T.Y. On the labor-scoring system for participation in minority tourism communities: A case study of Langde upper village. J. Guizhou Univ. Natly. 2010, 30, 189-193. (In Chinese)

123. Yu, K. Globalization and Changes in China's Governance; Brill: Leiden, The Netherlands, 2008.

124. Wall, G. Planning for Ethnic Tourism; Farnham: Ashgate, UK, 2014. 
125. Bennis, W.; Nanus, B. Leaders: The Strategies for Taking Charge; Harper and Row: New York, NY, USA, 1985.

126. Zhang, X.; Ding, P.; Bao, J. Patron-client ties in tourism: The case study of Xidi, China. Tour. Geogr. 2009, 11, 390-407. [CrossRef]

127. Colliers, P. Complexity and Postmodernism; Taylor \& Francis: London, UK, 1998.

128. Mumford, M.D.; Marks, M.A.; Connelly, M.S.; Zaccaro, S.J.; Reiter-Palmon, R. Development of leadership skills: Experience and timing. Leadersh. Q. 2000, 11, 87-114. [CrossRef]

129. Heifetz, R.; Grashow, A.; Linsky, M. The Practice of Adaptive Leadership; Harvard Business Press: Boston, UK, 2009. 